УАK 327:321.01

ББК 66.4(0)+66.01

DOI 10.22394/1682-2358-2018-3-106-115

A.A. Kovalev, Candidate of Sciences (Politics), Docent at the Public Administration Department, North-West Institute of Management, Branch of the Russian Presidential Academy of National Economy and Public Administration

E.A. Musin, post-graduate student at the Public Administration Department, North-West Institute of Management, Branch of the Russian Presidential Academy of National Economy and Public Administration

\section{MILITARY SECURITY AS A PROBLEM OF PHILOSOPHY OF POLITICS}

Ontological, praxiological, ethical, historical and logical facets of the concept of "military security" are analyzed. It is grounded that the military security of Russia can not be reduced to the number of structural elements. The military security is considered as a specific state of relations between a country and its possible opponents due to the complex political, economic, military and other factors.

Key words and word-combinations: power, military security, theory, politics, philosophy.
A.A. КовалеВ, кандидат политических наук, дочент кафедрь государственного и муниципального упраљления Северо-Западного института управления - филиала Российской академии народного хозяйства и государственной службь при Президенте РФ (email: senator23@ yandex.ru)

Э.А. Мусин, аспирант кафедри государственного и муниципального управления СевероЗападного института управления - филиала Российской академии народного хозяйства и государственной службь при Президенте РФ (етаil: edvinspb@gmail.com)

\section{ВОЕННАЯ БЕЗОПАСНОСТЬ

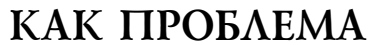 ФИКОСОФИИ ПОАИТИКИ}

Аннотация. Проанализированы онтологические, праксеологические, этические и историкологические аспекты понятия «военная безопасность». Доказывается, что военная безопасность России не сводится к числу составляющих структурных элементов. Военная безопасность рассматривается как особое состояние отношений между страной и ее возможными противниками, обусловленное комплексом политических, экономических, военных и других факторов.

Ключевые слова и словосочетания: власть, военная безопасность, теория, политика, философия.<smiles>[18OH]</smiles>
илософия политики - важная составная часть социамьной философии, которая в последнее время начинает становиться все более актуамьной в общем комплексе социально-гуманитарных наук. В своей 
предметной области философия политики во многом совпадает с теоретической политологией, которую можно рассматривать как преемника соџиальной философии, весьма быстро ставшей на ноги в соџиокультурной реальности ХX в. В наступившем столетии политики обязаны решать сложнейшие внутри- и внешнеполитические задачи, но одной из главнейших явмяется обеспечение комплексной безопасности страны.

В системе комплексной безопасности важнейшее место занимает военная безопасность - устоявшееся понятие, которое во всех европейских языках возникцо с момента зарождения государственности и самой цивилизации. Аостигнуть действенных успехов в деле укрепления военной безопасности без повышения уровня теоретического понимания данной проблемы невозможно. Теоретическое понимание проблемы военной безопасности немыслимо без применения методологической базы философии политики, которая сама по себе обширна и многоаспектна. С целью рассмотрения некоторых аспектов проблемы военной безопасности в контексте философии политики обратимся к онтологическим, праксеологическим, этическим и историко-логическим особенностям понятия «военная безопасность». Отметим, что все эти грани тесно переплетаются Аруг с Аругом, образуя неразрывное единство системного качества военной безопасности, поэтому сама военная безопасность не сводима к числу структурных элементов, ее составцяющих.

За всю историю существования философии проблемы войны и мира, безопасности и экзистенџиальных угроз часто становицись преАметом углубценной рефлексии. Вопросы обеспечения военной безопасности государства находици

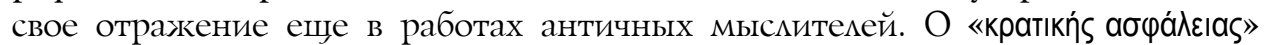
(государственной безопасности) рассуждали как первые преАставите и мюбомудрия Фалес и Гераклит, так и столпы «высокой классики» Сократ, Пцатон и Аристотемь.

Платон отмечал в диалоге «ФеАон», что война разгорается из-за жажды темесных удовольствий и требуемых Амя реализации этой цели богатств [1, с. 16] . К справедливым войнам Пцатон относил войны оборонительные или направменные на восстановцение справедливости и полагац, что ничто не Аолжно отвцекать воинов от обеспечения военной безопасности. Основная цемь воинов - это сохранение мощи и целостности государства. Сущность безопасности, по его мнению, - это предотвращение вреда [2, с. 275].

Аристотель считал, что дия защиты государства и его граждан необходимы спещиальные социальные институты, предназначенные для обеспечения мира [3, с. 307]. Стагирит видец справедиивость войны в защите от врагов и установцении наилучшего правления наА варварскими народами. И Пцатон, и Аристотель различали строгие нормы войны в отношении соседей-греков и более слабые - в отношении варваров, к которым возможно применение методов, неприемлемых к эмлинам. Как видим, политика Авойных стандартов имеет Аавнюю историю в соџиокультурной и политической практике человечества. Проблема военной безопасности нередко решалась в зависимости от господствовавшей в ту или иную эпоху формы идеологии, зависевшей от опреАеленных этических воззрений. Онтология военной безопасности теснейшим 
образом была связана с этикой и аксиологией. Ценность самой безопасности имела человеческое, соџиальное и культурное значение, а безопасность рассматривалась как явление действительности, как нечто сущее. Разцичное понимание добра и зма, блага и вреда не могло не сказаться на трактовках проблем войны и мира - порой диаметрально противоположных у разных мыслителей.

Гай Юлий Цезарь считал, что безопасность должна обеспечиваться вооруженной симой $[4$, с. $430-439]$, хотя уже Геродот в своей «Истории» сообщает об античных формах информаџионной войны и своеобразных «идеологических диверсиях». В пятой книге великого труда излагается, как Аристагор Микетский искусным психологическим воздействием уговаривает персидского сатрапа скмонить царя к захвату Наксоса, Пароса, Андроса и других КиклаАских островов, а также города Евбеи [5] .

Постепенно трансформация самой сущности войны приводит к изменению понимания военной безопасности. Совершенствование способов истребления себе подобных толкало мюдей на изучение разнообразных подходов к проблеме безопасности, в том числе и военной, ибо мюдей в человеческой истории чаше всего истребляли на войне - величайшей опасности для единичного и общего социального бытия.

Алительные и суровые военные действия служили Аля мюбой цивияизации проверкой на прочность. Великая европейская цивилизаџия возникла в Греции, структурно и законодательно окрепла в Римской республике и впосмедствии в империи, а окончательно сформировалась в Европе. Новая и свежая кровь европейских народов влилась в жилы греко-римской цивилизации. Европейская цивилизация триумфально пошиа по миру. Отнюдь не погруженные в наркотический сон индусы с их верой в нирвану, а деятельные европейџы создали паровой котел, открыли Америку и создали «ИАиаду», «Божественную комедию» и «Фауста».

Весь современный мир - продукт пассионарности европейской цивилизации, если использовать терминологию великого мыслителя $\Lambda . Н$. Гумилева. Бывшие варвары распространяли свои ценности не только мирным путем, но преимущественно огнем и мечом. Благие цели достигались порой весьма спорными среАствами, среАи которых война занимаха главенствующее место. Особо подчеркнем, что христианская западная цивилизаџия была создана сильными телом и духом, воинственными, гетеросексуальными и абсолютно неполиткорректными Аюдьми, убежкенными в превосходстве своего этноса, религии и культуры. С Аругой стороны, все негативные тенденции и кризисные явления современной эпохи (экологический кризис, аннигимяџия нравственности, военные конфликты) также, по большей части, явцяются результатом развития западноевропейской цивилизации. Сама война может быть понята как превышение меры здоровой агрессивности и неуживчивости, которая жизненно необходима дмя возникновения мюбой цивилизации. Желание доказать свою правоту, в том числе и военной силой, коренится в природе западного человека. В этом - диалектическая связь силы и слабости западной цивицизаџии, где џенность часто оборачивается антиџенностью, а Аобро - зАом. 
В Новое время Эразм Роттердамский утверждал, что обеспечение безопасности возможно не только военными средствам [6]. Несколько ранее Уи-

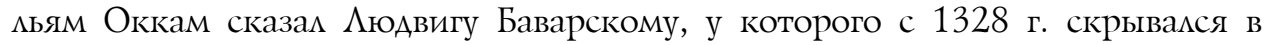
Мюнхене от преследований Папы Римского: «Защищай меня мечом, а я буду защищать тебя пером». По сути, вся христианская цивилизаџия базируется на признании важности Слова, понимаемого как Аух, Аогос, способный убивать и воскресать: «В начаме бымо Слово, и Слово было у Бога, и Слово было Бог» (Иоанн 1:1). Искусно сказанное и вовремя употребленное слово могло не только вызвать войну, но и предотвратить кровопролитие.

Эти мысли находим в трансформированном виде в воззрениях выдающихся политологов современности. Такие исследователи, как В.К. Потехин, В.И. САипченко подчеркивают, что применение вооруженного насилия отнюдь не всегда является опредемяющим признаком военного столкновения межАу государствами [7;8]. Если придерживаться такой точки зрения, то Третья мировая война уже идет полным ходом. Ведь и в 1930-е годы военные действия велись в разных регионах земного шара до того, как разразияся мировой военный пожкар, а накал идеологической борьбы был обжкигающе горяч.

Ааже после нападения Германии на Польшу 1 сентября 1939 г. никто из политиков того времени не говориц о том, что началась Вторая мировая война. Ааже само слово «война» ими не употребцялось. Немеџкая офиџиальная пресса писала о военных действиях в Польше как о «борьбе за мир в Европе», советские пропагандисты после 17 сентября 1939 г. именовали раздел и уничтожение Польши «защитой братских народов» - правда, без уточнения того обстоятельства, от кого эти народы защищаемы. Итальянская пресса вторжение Гитлера в Польшу трактовала как «выполнение миротворческой миссии».

Сегодня часто вспоминают о разцичных трактовках стратегии непрямых действий сәра Б. Аиддел Гардта, бывшего современником двух мировых войн и самых разнообразных кризисов, в том числе и Карибского [9]. Традиџионное понимание войны устарело и не отвечает в полной мере среде безопасности в XXI в. Мысли АиАлем ГарАта о том, что для достижения победы противника нужно мюбой ценой вывести из равновесия, активно используются Аля стратегии современной информационной войны, а создание действенной стратегии такой войны невозможкно без мощной политико-философской базы.

При рассмотрении состояния военной безопасности России как проблемы фимософии политики в современной ситуации смедует учитывать, что войны как явление соџиокультурной реальности всегда возникают как следствие неразрешимых противоречий в межкосударственных отношениях. Эти противоречия, как и некоторые болезни, хотя порой и загоняются внутрь обшественных организмов, но все равно рано или поздно проявляются, и нередко это происходит самым роковым образом.

Ныне уже нет противостояния двух обшественно-политических систем, но налицо противостояние цивилизаций, возникшее из-за неразрешенных цивилизационных противоречий. В последние годы наблюдается тенденция к возрождению Русского мира как геополитического единства. Само поня- 
тие «Русский мир» в современную эпоху стало интенсивно употребцяться отечественными соџиальными философами, историософами и политологами после встречи В.В. Путина с творческой интемиигенцией в Аоме Аержавина в Санкт-Петербурге. Именно тогда, в канун Года русского языка, Президент РФ в качестве важнейших составляющих Русского мира выделил "русское слово» и «русскую культуру». В.В. Путин тогАа отметил: «Русский мир может и Аолжен объединить всех, кому дорого русское слово и русская культура, где бы они ни жили, в России или за ее пределами. Почаще употребцяйте это словосочетание - «русский мир». Пожелание Президента РФ было выполнено соџиальными философами и политологами, и дискуссии о Русском мире как о некоей общности принями оживленный характер.

И пусть пока само это понятие носит по большей мере культурологический и идеологический оттенок, но налиџо и практические шаги, преАпринятые в проџессе создания и укрепления Евразийского экономического союза, созданного при ведущем активном участии России 1 января 2015 г.

Сама возможность укрепления позиџий России вызывает активное противодействие Запада. Идеологические схватки превращаются в борьбу геополитических конџепций. ГАавное, чтобы при этом не страдала истина, ибо она вновь - и уже давно - в ряде научных исследований как на Западе, так и в нашем Отечестве, в некоторых секторах общественно-политического знания запрещена. Господствует идеология в самых разнообразных формах и модификациях. Если же истина противоречит идеологии, то эта истина объявмяется преступной. Именно поэтому важно не повторять ошибок советского времени, когда безграмотные идеологи в 1970-1980-е годы привели державу к Ауховному вакууму и экономическому краху. Важно также не опуститься до уровня западных «прогрессивных» политологов, Аля многих из которых основным методом научной дискуссии явцяется иишь стройная и продуманная система оскорблений оппонентов.

В современную эпоху происходит унификация мира по американским станАартам, и этот процесс угрожает наџиональной безопасности многих стран, в том числе напрямую и военной безопасности России. Этот процесс красиво именуют глобализацией. Как отмечает П.А. Горохов, «глобализация - всеохватывающий, многоаспектный проџесс насильственного превращения мира в целостную и унифицированную по западным стандартам систему, совпадающий, по сути дела, с Третьей мировой войной, которая ведется развитыми странами Запада против остального мира» [10, с. 44$]$.

Сама военная безопасность Аюбой страны напрямую связана с ее вмастными структурами. Т. Гоббс акцентировац внимание на том, что у верховной власти есть право объявления войны и заключения мира [11]. Мыслитель много рассужАал о войнах, причины которых коренятся в человеческой природе, склонной в агрессии. В своем труде «Аевиафан» философ опровергал старую истину Аристотеля о том, что человек является по природе своей обшественным сушеством.

Но подлинной безопасности можно достичь Аишь при отказе от состояния «войны всех против всех», от «права всех на все». Аюди заключают об- 
щественный Аоговор, суть которого заключается во взаимных обязательствах межАу поАчиняющим и поАчиняющимися. Именно государство - главный гарант всеобщей безопасности. Государство призвано соблюдать нерушимость

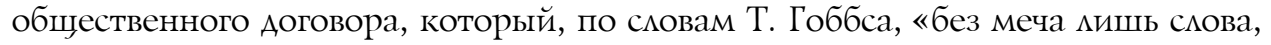
которые не в сицах гарантировать человеку безопасность» [12, с. 338]. Ныне эти мысли кажутся трюизмом, но в эпоху зарождения капитализма и создания новых общественно-политических конџепџий идеи Т. Гоббса были струей чистой воды в замутненном болоте средневековых предрассудков.

Собственно, именно Т. Гоббс и Аж. Аокк явмяются творџами теории безопасности, которая стала утверждаться в Новое время и оказала значительное влияние на идеологию и практику европейских государств, в том числе созданных на основе философских и правовых идей Аж. Мокка Соединенных Штатов Америки. Именно мысли и доводы, содержащиеся в его произведении «Ава трактата о государственном правлении» [13], американские комонисты испоцьзоваци в своей борьбе против королевской вмасти во время Американской револющии.

Война непосредственно связана с политикой и имеет политическое содержание. Так было всегда, но с возникновением капитацизма в Европе политические интересы стали довлеть наА прочими и определять состояние войны и мира. К началу ХІХ столетия, в бурную эпоху наполеоновских войн, определимись основные контуры теории войны и военной безопасности. ЗАесь нельзя не вспомнить о кмассической книге Карла фон Клаузевица «О войне», созданной в 1832-1837 гг. и призванной осмыслить величественную Наполеоновскую эру, порожденную кровавой и великой Франщузской револющией. По К. КАаузевицу, война явцяется рационально организованным инструментом национальной политики. Безопасность - состояние, свободное от военной угрозы. ЗАесь К. КАаузевиџ рассуждает в русле основных конџепџий немеџкой классической философии, согласно которым разум довлеет наА природой и рационально можно постичь все загадки мироздания. Военный теоретик вполне могично и рационально связал войну и политику. «Война есть не что иное, как продолжение политических отношений с привнесением иных средств» [14, с. 101].

К. КАаузевиџ подчеркивац, что войны не возникают внезапно, но Аолго и тщательно подготавливаются национальными правительствами, проводящими определенную политику. Война, являясь частью единой системы, мишь продолжает в иной форме предшествующую политику государства. Политика порождает войну, а не наоборот. Если же правительство начало войну, то

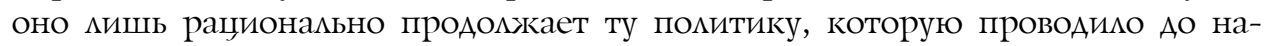
чала военных действий. Мирная политика призвана удовцетворить собственные эгоистические интересы, но если она не дает желаемых результатов, то государственная власть переходит к Аругой форме политики - войне, главной целью которой является сокрушение вражеской политики военными среАствами. Отсюда «война есть акт насилия, имеющий целью заставить противника выполнить нашу волю» [14, с. 3] .

Разумеется, в современную эпоху цели войн не всегда явцяются политическими в традиционном смысле, ибо меняются сами преАставления о Аолжном 
и сущем в политике. Эти цели не всегда эксплиџитно связаны с идеологическим и геополитическим выражением наџиональных интересов, но имплиџитно отражают эти интересы. Геополитика теснейшим, часто неявным образом связана с целым компиексом этнических и религиозных аспектов целей и Аостижением территориальной или языковой идентичности. Разумеется, само право применять вооруженное насилие при ведении войн в современную эпоху принадлежит не только заинтересованным государствам, но и союзам госуАарств и транснационацьным корпорациям.

Суть военной безопасности Аля России - предотвращение войны, которая угрожала политической и соџиокультурной џелостности страны на протяжении всей ее истории. ЗАесь онтологическая сущность явления сливается с праксеологической стороной. Некоторые аспекты проблемы военной безопасности в условиях силового противостояния цивилизаций в цогико-историческом аспекте уже рассматривались в преАшествующих работах [15] . Отечественные мыслители часто обращались к проблемам войны и военной безопасности, ибо война быма перманентным явлением мия русской истории. Гигантская территория России с богатейшими мюАскими и природными ресурсами издревле манила к себе захватчиков.

Выдающийся историк М.Н. Покровский совершенно справедииво отмечал, что история - это политика, опрокинутая в прошиое. Порой историк-большевик утвержАац, что история есть политика прошиого, без которой нельзя понять политику настоящего. Видимо, эта максима явцяется парафразом мысми британского историка ЭАварда Фримана: «История есть политика прошлого, а политика - история настоящего» [16] .

Фактически на протяжении всей своей государственной истории России пришлось отражать удары завоевателей, мечтавших захватить богатые и обширные просторы Руси. В начале XVII столетия Россия оказалась под угрозой потери государственности, которая была восстановцена не усилиями верховной власти, а инициативой снизу - народным ополчением, созванным в Нижнем Новгороде под руководством князя Амитрия Пожарского и гражАанина Кузьмы Минина.

Именно вечная необходимость отражкать удары многочисленных внешних врагов нашла свое отражкение в самой этимологии русского слова «безопасность». Этимологически термин «безопасность» означает состояние свободы от цюбой возможнной опасности, что подчеркивал В.И. Ааль в своем великом Словаре. Он определяет слово «безопасность» как «отсутствие опасности; сохранность, надежность». Аалее читаем: «Безопасливый, ничего не опасающийся, неосторожный, самонадеянный, смелый и опрометчивый; безопасливость - свойство, качество». В контексте рассматриваемой тематики интересна поговорка, которую приводит в этой словарной статье В.И. Ааль: «Безопасливость губит» [17, с. 67] .

Немецкое слово die Sicherheit означает «безопасность» и «уверенность», а могика и корни английского security и французского la sécurité коренятся в матинском слове securitas, которое означает состояние уверенности, надежности, стабицьности и беззаботности. Собственно, и это матинское слово произошио от древнелатинского sesed (без) и сига (забота). 
В аксиологическом аспекте саму свободу как величайшую ценность можно понимать как в положительном («свобода Аля»), так и в отрицательном («свобода от») аспектах. Военная безопасность как состояние свободы Амя мирного и творческого труда всегда была идеалом для русских патриотов. Военная безопасность, сама выступая одной из высших ценностей, дава^а возможность развиться высшим духовным потенциям народа. В этом - главный аксиологический аспект военной безопасности.

Ао 1990-х годов отечественная социально-политическая мысль военную безопасность вполне могично ассоџиировала с понятием защиты соџиалистического государства и укреплением его обороноспособности. Огромную роль играл соџиалистический патриотизм. В ельцинские годы наА патриотизмом посмеивались разные обшественно-политические деятели, обанкротившиеся политики, мюто ненавидевшие Россию, особенно Аюбили вспоминать афоризм поэта Самуэмя Ажонсона «Патриотизм - последнее прибежище негодяя» (Patriotism is the last refuge of a scoundrel). С начама 2000-х годов смешки по поводу патриотизма, патриотов и необходимости укреплять безопасность страны стали затихать, но окончательно исчезли, мишь когАа в феврале 2016 г. В.В. Путин объявиц патриотизм наџиональной идеей России.

В 1994 г., в разгар ельцинского безвременья, мауреат Нобелевской премии мира и бывший Государственный секретарь США Г. Киссинджер, изрек:

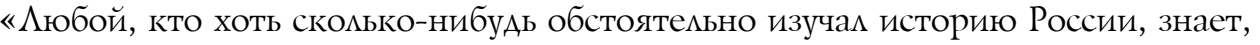
что именно русский национализм всегда обеспечивац целостность страны и ее способность справляться с многочисленными врагами и бедами» [18]. На наш взгляА, экс-политик верно уловиц основную философскую составцяюшую наџиональной идеи России, которой она была верна во всех государственнополитических формах на протяжении своей истории (Киевская Русь, Московское царство, Российская империя, Советский Союз). Г. Киссинджер считается не только выдающимся американским интемлектуалом, но и инициатором и главным проводником политики разрядки в отношениях США и Советского Союза. Г. Киссинджер тщательно изучал русскую историю и китературу, поэтому резюмировал свои наблюдения пророчески: «А ныне русские потеряли созАанную ими огромную империю. Можно $и$ рассчитывать на какую-то иную реакцию на это унижение, нежели взрыв национализма?» [18] .

Пусть иностранџы именуют русский патриотизм наџионализмом! Из-за этого вовсе не стоит отрекаться от самих себя и великой истории своего государства Аишь потому, что кому-то хочется называть наше Отечество посмедней империей в мире, а русский патриотизм именовать наџионализмом. Степень военной безопасности напрямую связана с уровнем патриотизма, ибо безопасным может считать себя мишь государство, свободное от внутренних распрей и способное в мюбой момент отразить внешнюю опасность силами как армии, так и всего народа.

Патриотизм - диалектический синтез онтологической и аксиологической составцяющих духовности, без которого невозможна безопасность страны. Сохранение и приумножение традиџионных российских духовно-нравственных ценностей как основы российского общества явмяется стратегической 
целью национальной безопасности, согласно Указу Президента РФ от 31 декабря 2015 г. № 683 «О Стратегии национальной безопасности Российской Федерации». 7 мая 2018 г., после инаугурации Президента РФ, был издан Указ «О национальных џемях и стратегических задачах развития Российской Федерации на период до 2024 года». Аанный документ направмен на укрепмение российской гражданской идентичности на основе духовно-нравственных и культурных ценностей народов Российской Федераџии.

Таким образом, очевидно, что само понимание термина «военная безопасность» в разных исторических эпохах у различных мыслитемей варьировалось, различается оно и у современных мыслителей - политологов, философов, юристов. Например, военную безопасность можно понимать «как состояние жкизнедеятельности социума, его структур и институтов, гарантирующее их качественную определенность в параметрах надежности существования и устойчивости развития посреАством исключения военного насилия» [19, с. 81-82].

Разиичные аспекты безопасности - экономические, политические, психомогические и т.А. - исследуются уже в течение столетий. ОАнако к середине XX столетия явственно высветилась необходимость обобщения множества эмпирических данных и отдельных теоретических положений. Необходим синтез знаний о самом феномене безопасности, создание системной конџепџии обеспечения безопасности. Многие ученые и в России, и за рубежом приступили к активному исследованию проблем, связанных с обеспечением национальной и межАународной безопасности. ОАнако существенные разАичия в подходах к трактовке социальных процессов, к объяснению их могики также явились причиной возникновения большого количества конџепџий иногАа АОполняющих Аруг Аруга, а нередко и противоречащих Аруг Аругу.

Итак, рассмотрев онтологические, праксеологические, аксиологические, этические и историко-логические особенности понятия «военная безопасность», можно сделать вывоА, что военная безопасность России не сводима к числу составмяющих структурных элементов, так как образует внутреннее и внешнее единство. Онтология теснейшим образом связана с праксеологией, а этика - с аксиологией, которая, в свою очередь, базируется на сущностной основе. Аогика исторического проџесса высвечивает экзистенциальную и онтологическую проблематику.

Тем не менее следует констатировать, что искмючить возникновение мокальных военных действий в эпоху противостояния цивилизаций чрезвычайно сложно. По сути, в мире уже вспыхнули очаги новой мировой войны, и если в ближайшее время их не удастся погасить, то грядущая мировая катастрофа станет неизбежной.

Создать, сохранить и укрепить состояние военной безопасности немьзя без перманентного анализа меняющейся ситуации, в котором должны быть задействованы философы, политологи, юристы, экономисты и культурологи. Реальная жизнь намного богаче самых объемных и всеохватных философских концепций, но, по нашему убеждению, именно философия политики может послужить нитью Ариадны в кабиринте международных и геополитических противоречий. Исходя из сложившейся соџиокультурной и геополитической 
ситуации противостояния цивилизаций в современном мире, военную безопасность России в качестве предмета анализа философии политики можно определить как диалектическое состояние отношений межАу Россией и ее возможными противниками, обусловценное комплексом политических, экономических, военных и Аругих противоречий, сглаживание или разрешение которых призвано искцючить возможность Третьей мировой войны.

\section{Библиографический список}

1. Платон. Собрание сочинений: в 4 т. М., 1994. Т. 2.

2. Платон. Диалоги. М., 1986.

3. Аристотель. Политик. СПб., 1911.

4. Цезарь Г.Ю. Записки Юлия Цезаря и его продолжателей о Галльской войне, о Гражданской войне, об Александрийской войне, об Африканской войне. М., 2007.

5. Геродот. История. М., 2007.

6. Роттердамский Э. Воспитание христианского государя. Жалоба мира, отовсюду изгнанного и повсюду сокрушенного. Похвальное слово глупости. М., 2001.

7. Потехин В.К. Современные войны и национальная безопасность России // Кому будет принадлежать консциентальное оружие в XXI веке?: сборник статей / гл. ред. Ю.В. Крупнов. M., 1997. C. 69-87.

8. Слипченко В.И. Войны шестого поколения. Оружие и военное искусство будущего. М., 2002.

9. Лиддел Гарт Б.Г. Стратегия непрямых действий. М., 1957.

10. Горохов П.А. Глобализация: опыт философского осмысления // Вестник Оренбургского государственного университета. 2007. № 7. С. 44-50.

11. Гоббс Т. Левиафан, или материя, форма и власть государства церковного и гражданского // Гоббс Т. Соч.: в 2 т. М., 1991. Т. 2. С. 139-140.

12. Антология мировой философии: в 4 т. Т. 2: Европейская философия от эпохи Возрождения по эпоху Просвещения. М., 1970.

13. Локк Д. Два трактата о государственном правлении. М., 2009.

14. Клаузевии К. О войне. М., 1933.

15. Ковалев А.А. Информационная политика и военная безопасность России в эпоху противостояния цивилизаций: теоретико-методологические аспекты проблемы. СПб., 2016. 2005.

16. Энциклопедический словарь крылатых слов и выражений / авт.-сост. В. Серов. М.,

17. Даль В.И. Толковый словарь живого великорусского языка: в 4 т. М., 1995. Т. 1: А - 3.

18. Kissinger I.W. A Biography. New York: Simon \& Schuster, 2005.

19. Радиков И.В. Военная безопасность общества и государства: политологический анализ: дис. ... д-ра полит. наук. СПб., 2000. 